\title{
Magyarországi vegetációtüzek keletkezési okainak vizsgálata és osztályozása
}

\section{Study and Classification of the Causes of Wildfires in Hungary}

Az erdő- és vegetációtüzek okainak megértése kiemelkedő jelentőségü az erdőtüzmegelőzési tevékenység, valamint a környezet- és lakosságvédelmi intézkedések megtervezésében. Hazánkban a klimatikus viszonyok és a vegetáció összetétele miatt természetes úton alig keletkezik vegetációtüz. A vegetációtüzek többsége emberi gondatlanság következménye. A tüzkockázat értékelésének hatékonyságát növeli, ha értjük a vegetációtüzek okait, a tüzet gyújtó személyek motivációit. Az erdőtüz megelőzésért felelős hatóságok a 2011-2020 közötti időszakban végzett adatgyüjtése során megismert tüzokok elemzésével lehetőség van a magyarországi vegetációtüzek antropogén eredetének vizsgálatára, a szocioökonómiai faktorok meghatározására, ami a későbbiekben alapja lehet a vonatkozó célzott kommunikáció célcsoportjai meghatározásának. Az Európai Erdőtüz Információs Rendszer tüzkeletkezésiok-sémájával való összevetés alapján javaslatok tehetők a hazai rendszer harmonizálására.

Kulcsszavak: vegetációtüz, tüzkeletkezési ok, Katasztrófavédelmi Adatszolgáltató Program, Országos Erdőtüz Adattár, Európai Erdőtüz Információs Rendszer

Understanding the causes of wildfires is of paramount importance in the planning of forest fire prevention activities, environmental and civil protection measures. The probability of wildfires occurring naturally is very low due to the climate and vegetation conditions in Hungary. Most wildfires are caused by human negligence. The effectiveness of a wildfire risk assessment can be increased if we understand the causes of wildfires and the motivations of those who set fires. By analysing the fires identified during the data collection of the forest fire prevention authorities in the period of 2011-2020, it is possible to examine the anthropogenic origin of wildfires in

Nemzeti Közszolgálati Egyetem Katonai Műszaki Doktori Iskola, doktori hallgató, e-mail: DebreceniP@nebih. gov.hu 
Hungary and define social economic factors, which may later be the basis for defining the target groups of relevant targeted communication. Based on the comparison with the fire generation scheme of the European Forest Fire Information System proposals can be made for the harmonisation of the Hungarian system.

Keywords: wildfire, cause of fire, Data Gathering System of the Disaster Recovery Service, Forest Fire Database of Hungary, European Forest Fire Information System

\section{Bevezetés}

Az erdő- és vegetációtüzek okainak megértése kiemelkedő jelentőségű az erdőtűzmegelőzési tevékenység során. Hazánkban, a klimatikus viszonyok és a vegetáció összetétele miatt természetes úton az esetek kevesebb mint egy százalékában keletkezik vegetációtűz. A vegetációtüzek többsége emberi gondatlanság, illetve néhány esetben szándékosság következménye. A hatósági adatgyűjtésből kinyert információk alapján a tüzeket elsősorban az autóból, vonatból, kerékpárról kidobott, eldobott cigarettacsikkek, a hanyagul ott hagyott tábortüzek, a gondatlanul végzett kiskerti és tarlóégetések, a rosszul szervezett grillezés és bográcsozás vagy az erdőterületen helytelenül kivitelezett vágástéri hulladékégetések okozzák. A tűzkockázat-értékelés hatékonyságát nagyban meghatározza és növeli, ha értjük a tüzek okait, a tüzet gyújtó személyek motivációit. Az adatgyűjtés során megismert tűzokok elemzésével lehetőség van az erdőtüzek antropogén eredetének vizsgálatára, a szocioökonómiai faktorok és a célzott kommunikáció célcsoportjainak meghatározására.

A cikk megírásával a célom a 2011 és 2020 között keletkezett vegetációtüzek okainak vizsgálata, továbbá a hazai adatgyűjtési rendszerben rögzített tűzokok összehasonlítása az EFFIS, ${ }^{2}$ vagyis az Európai Erdőtűz Információs Rendszer tűzoksémájával. További cél a hazai és az európai rendszer közötti eltérések feloldására irányuló javaslat összeállítása.

\section{Vizsgálati módszer}

A hatékony erdőtűzmegelőzési tevékenység alapja a megfelelő részletességű adatgyűjtés, amelynek segítségével leírhatók a vegetációtüzek keletkezési körülményei, a tűzben károsodott terület paraméterei, információkat kaphatunk a tűz keletkezési okáról és a tűzoltói beavatkozás során megtett intézkedésekről. A 2011 és 2020 között keletkezett erdő- és vegetációtüzek vizsgálatához létrehoztam egy térinformatikai adatbázist, amely tartalmazza a katasztrófavédelem és az erdészeti hatóság által a tüzesetekről rögzített adatokat, a keletkezés időpontjában fennálló tűz időjárásiindex-értéket, amely a meteorológiai körülményekből fakadó tủzkockázatot jelzi. Ezenfelül térbeli elemzéseket végeztem és egyéb számított, származtatott paramétereket adtam hozzá az egyes tűzesetek leíró adataihoz, amelyek segítségével térbeli és időbeli mintázatokra vonatkozó vizsgálatok is végezhetők a későbbiekben.

2 Az angol mozaikszó (EFFIS) feloldása: https://effis.jrc.ec.europa.eu/ 
A szabad területen keletkező tűzesetek leíró adatainak rögzítése során a helyszín jellege szerint három kategóriába sorolják a tüzeseteket. A létesítmények szabad terei jellemzően azokat a belterületi kerítéssel határolt ingatlanokon, épített környezetben keletkezett tüzeket jelölik, amelyek területén növényzetet is érintett a tűz. Ilyen esemény lehet lakóház, tanya udvarán vagy parkban égő aljnövényzettűz. A szabad területen, fával borított területen vagy annak határán, jellemzően külterületi ingatlanokon meggyújtott hulladék vagy növényi maradványok szintén külön kategóriát képviselnek. A szabad területen keletkezett tűzesetek közül azok minősülnek vegetációtűznek, amelyekben a tűz a természetes növénytakaróban keletkezett vagy arra átterjedt. Értelemszerűen a vegetációtüzek egy részhalmazát jelentik az erdőtüzek, amikor a tüz nem szükségszerüen az erdőből indult ki, és nem kizárólagosan, de teljesen vagy részben erdőt vagy fával borított területet is érint. Az erdőtűz definíció megfelel az EFFIS-ben megadott erdőtűzfogalomnak.

A 2011-2020 közötti évtizedben a szabadterületi tűzesetek száma az első két év kiemelkedő értékei után csökkenést mutat. Az utóbbi négy évben enyhe emelkedés tapasztalható, amely jellemzően az egyenetlen csapadékeloszlással és az emberi tevékenységgel magyarázható. Jelen kutatásnak nem tárgya a tűzesetszámok mögött meghúzódó klimatikus és egyéb tényezők vizsgálata. Esetünkben annyit érdemes kiemelni, hogy az elmúlt évtizedben a tüzoltói beavatkozással érintett erdő- és vegetációtüzek száma átlagosan 27,8 \%-át tette ki az összes éves tüzesetszámnak (1. ábra).

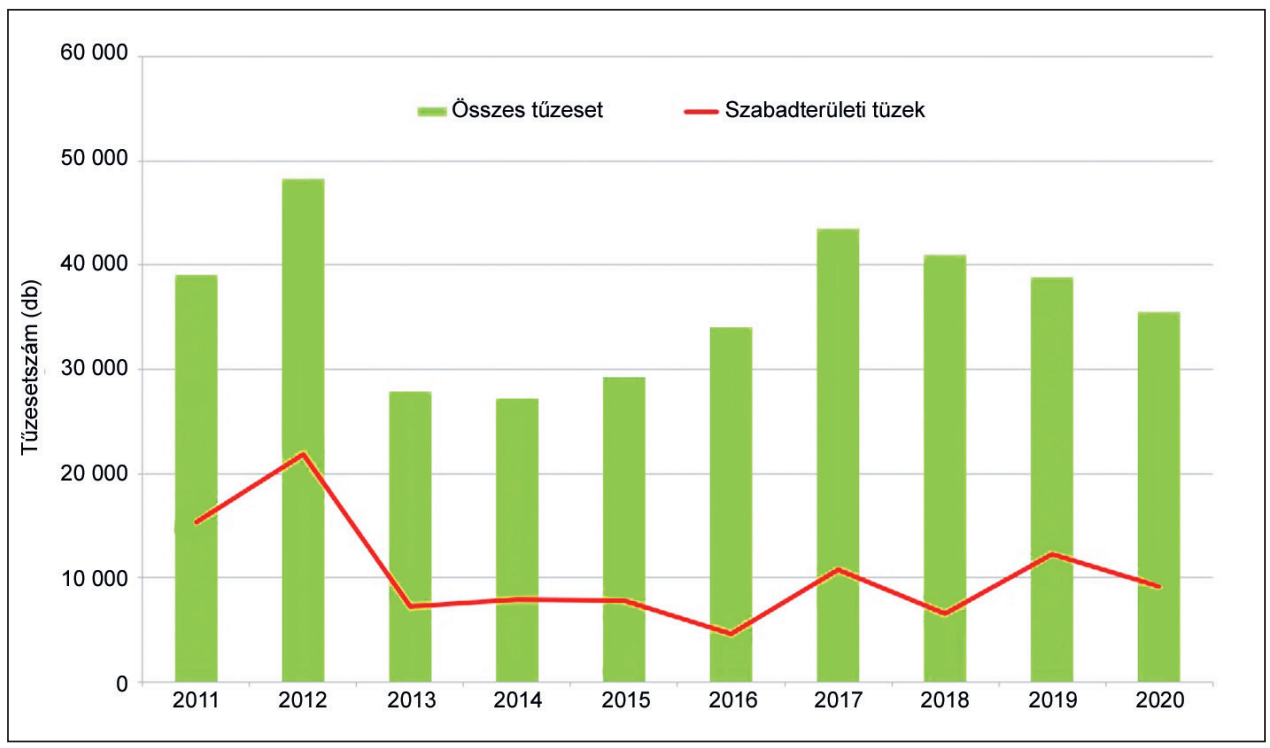

1. ábra. Összes tüzeset és a szabadterületi tüzek száma évente 2011-2020 között Forrás: a szerző szerkesztése a BM OKF KAP Online és a NÉBIH Erdőtűz Adattár adatai alapján

A 2. ábrán látható a vizsgált időszakban keletkezett szabadterületi tűzesetek éves alakulása, illetve a vizsgálatba bevont azon erdő- és vegetációtüzek száma, amelyeknél tüzoltói beavatkozás történt. 


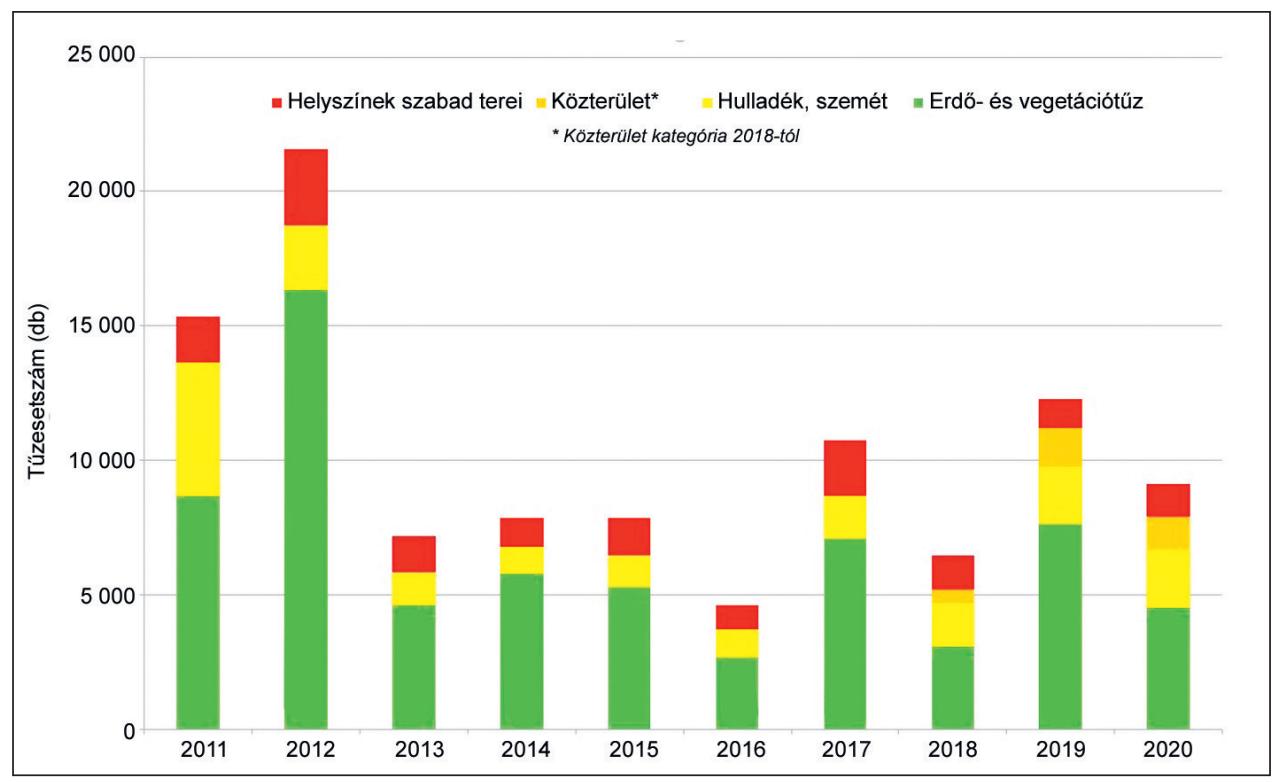

2. ábra. Szabadterületi tüzek száma évente 2011-2020 között

Forrás: a szerző szerkesztése a BM OKF KAP Online és a NÉBIH Erdőtűz Adattár adatai alapján

A tüzek okainak vizsgálata során az összes vegetációtűz közül azokat vizsgáltam, ahol történt tűzoltó beavatkozás. A vizsgált időszakban 63175 ilyen vegetációtüzet regisztráltak. A beavatkozást igénylő eseménynél helyszíni adatfelvételezés történik, amikor a tűz keletkezési okára vonatkozó szakszerü megállapítások is rögzítésre kerülnek. A vegetációtüzek a vizsgált időszakban átlagosan 62,1\%-át tették ki az összes szabadterületi tűzesetnek, illetve a vegetációtüzek 96\%-ában történt tüzoltói beavatkozás.

A tűzkeletkezési okok vizsgálata során összevetettem a Tüzeseti és Müszaki Mentési Jelentés (TMMJ-)adatlapokon ${ }^{3}$ a tüzoltást vezető által rögzített tűzokot az Erdő és Vegetációtűz Felviteli Adatlapon (Erdőtűz-adatlap) található tűzokkal. A rögzített tűzkeletkezési okokat összevetettem az EFFIS tüzoksémájával, és áttekintettem a vonatkozó szakirodalmat.

\section{Az adatgyüjtés rendszere és jogszabályi alapja}

Az erdőtűz-megelőzésért és a védekezésért felelős kormányzati szervek, a Belügyminisztérium kötelékében működő Országos Katasztrófavédelmi Főigazgatóság (BM OKF) és a Nemzeti Élelmiszerlánc-biztonsági Hivatal (NÉBIH) együttműködésének köszönhetően létrehozásra került az EFFIS-nek megfeleltetett adatszerkezettel rendelkező adatbázis, amelynek segítsé-

3 A tűzoltási és műszaki mentési tevékenységről készülő adatszolgáltatást elsődlegesen a működési terület szerinti beavatkozó hivatásos tűzoltóság készíti az online Katasztrófavédelmi Adatszolgáltató Programban (másképpen: KAP Online). 
gével biztosított a szabványosított adatfelvételezés, az adatok archiválása és feldolgozása, a katasztrófavédelem és az erdészeti hatóság kölcsönös hozzáférése, valamint az adatszolgáltatás az EFFIS részére.

Az adatgyűjtés két ágazati jogszabály alapján történik. A tűz eloltása utáni helyszíni adatfelvételezést a tűzeset helyének megfelelő müködési terület szerinti beavatkozó hivatásos tűzoltóság végzi el. Az adatrögzítés szabályait a katasztrófavédelmi szervek és a tűzoltóságok tűzoltási és műszaki mentési tevékenységének adatszolgáltatási rendjéről szóló 6/2014. (III. 7.) BM OKF utasítás ${ }^{4}$ rögzíti. A helyszínen rögzített adatok a BM OKF által üzemeltetett online Katasztrófavédelmi Adatszolgáltató Programban (röviden: online KAP) 5 a Tüzeseti és a TMMJ Erdő és Vegetációtűz Felviteli Adatlapján (Erdőtűz-adatlap) kerülnek archiválásra az oltást végző egység beérkezése utáni 2 órán belül. Az erdőtűznek minősülő tűzesetek adatai az erdők tűzvédelméről szóló 4/2008. (VIII. 1.) ÖM rendelet (erdőtűzvédelmi rendelet) ${ }^{6}$ előírásai szerint vezetett Országos Erdőtűz Adattárban (röviden: Erdőtűz Adattár) ${ }^{7}$ kerülnek átolvasásra és eltárolásra, amit a NÉBIH üzemeltet. Az erdészeti hatóság helyszínelést csak akkor végez, ha a tűzeset során olyan mértékben károsodott a faállomány, hogy erdőművelési beavatkozás szükséges a kárfelszámoláshoz. A helyszíni ellenőrzést nem igénylő tűzesetek térinformatikai vizsgálat és az adatlapon megadott adatok alapján kerülnek minősítésre az Erdőtűz Információs rendszerben. A két adatállomány a tárgyév végén egyeztetésre, összevezetésre kerül. Az adatbázisban a tűzesetek a tűz helyével, a riasztás, beavatkozás és felszámolás időpontjával, a leégett terület kiterjedésével és a tűz feltételezett okának megadásával kerülnek leírásra. Az Erdőtűz-adatlapon rögzített tűzok kerül beolvasásra az Erdőtűz Adattárba. Ezenfelül szöveges megjegyzésben írják le a tűzeset felszámolása során tapasztalt, a tűz jellemzésében releváns információkat.

\section{Vegetációtűz keletkezési okai Magyarországon}

A TMMJ-adatlapokon három különböző adathelyen jelenik meg a tüzkeletkezési ok. Az első adatrögzítés a helyszínen történik, amikor a tűzoltásvezető által vélelmezett tűzkeletkezési okot kell feltüntetni az adatlapon. A megjelölt tűzok statisztikai célból kerül rögzítésre, ezért a vonatkozó szabályozás szerint nem szükséges annak bizonyítottsága vagy bizonyíthatósága. ${ }^{8}$

Vegetációtüzek esetében a TMMJ Erdőtűz-adatlapján is meg kell jelölni a tűz tényleges vagy feltételezett keletkezésének okát az erdőtűzvédelmi rendelet 17. § (1) h) pontjában megadott kategóriák valamelyikével. Az erdőtüzvédelmi rendelet az Európai Erdőtűz Információs Rendszer működtetéséről szóló 1737/2006/EK rendelet ${ }^{9}$ előírásai alapján határozza meg a rögzíthető

4 6/2014. (III. 7.) BM OKF utasítás a katasztrófavédelmi szervek és a tűzoltóságok tűzoltási és müszaki mentési tevékenységének adatszolgáltatási rendjéről.

5 A Katasztrófavédelmi Adatszolgáltató Program (KAP Online) adatai. Budapest, Magyarország Belügyminisztériuma, Országos Katasztrófavédelmi Főigazgatóság.

4/2008. (VIII. 1.) ÖM rendelet az erdők tűzvédelméről.

Az Országos Erdőtűz Adattár adatai. Budapest, Nemzeti Élelmiszerlánc-biztonsági Hivatal (NÉBIH).

6/2014. (III. 7.) BM OKF utasítás.

Az Európai Erdőtűz Információs Rendszer működtetéséröl szóló 1737/2006/EK rendelet. 
kategóriákat: 1. ismeretlen; 2. természetes; 3. balesettel vagy hanyagsággal, azaz emberi tevékenységgel kapcsolatos, de nem szándékos tủzokozás; 4. szándékosság, gyújtogatás.

Azokban az esetekben, amikor tűzvizsgálat indul, a tűzvizsgálat eredményeként megállapított tüzkeletkezési ok is rögzítésre kerül az adatbázisban. ${ }^{10} \mathrm{~A}$ kutatás során a tüzvizsgálat által megállapított tűzokot nem vizsgáltam. A célom az alapvető adatgyűjtésből kiolvasható információk kigyűjtése és összevetése volt, illetve a tűzvizsgálati gyakorlatra vonatkozóan készült már kutatás. ${ }^{11}$ A kutatásban a 2011 és 2020 közötti időszakban rögzített 63175 db beavatkozást igénylő vegetációtűz adatlapján rögzített tűzkeletkezési okokat vizsgáltam.

Az erdőtüzek okainak megértése kiemelkedő jelentőségű az erdőtűzmegelőzési tevékenység, valamint a környezet- és lakosságvédelmi intézkedések megtervezésében. A tűzkockázati értékelés hatékonyságát is nagyban meghatározza, ha a tűzben károsodott biomassza tulajdonságai mellett ismerjük és értjük a tüzek okait, a tüzet gyújtó személyek motivációit. Azonban a jelenlegi adatgyűjtési rendszerben korlátokba ütközik a tűz okainak feltérképezése és beépítése a kockázatértékelésbe. Ennek okait az alábbiakban részletezem. ${ }^{12}$

A vegetációtüzek keletkezési okait Nagy Dániel is vizsgálta 2008-ban az Erdőtüzek megelőzési és oltástechnológiai lehetőségeinek vizsgálata című doktori értekezésében. Kutatásában a katasztrófavédelmi adatbázisból kinyert adatok elemzése mellett terepi megfigyeléseket végzett, valamint erdész és tűzoltó szakemberekkel készített interjúkat a jellemző tűzkeletkezési okok kategorizálására. Munkájának egyik eredménye, hogy a gondatlanságból bekövetkező tűzeseteknél szétválasztotta a két büntetőjogilag definiált kategóriát. Erre azért volt szükség, mert eltérő típusú tüzekhez és célcsoportokhoz köthetők, egyes esetekben pedig földrajzilag is lehatárolhatók. ${ }^{13}$

Nagy Dániel hanyag gondatlanságnak (negligencia) minősítette azokat a vegetációtüzeket, ahol az elkövető nem látja elöre magatartása lehetséges következményeit, mert elmulasztotta a „tőle elvárható” figyelmet vagy körültekintést. Ilyen tűzesetek lehetnek a kirándulóhelyeken nem megfelelően eloltott tábortüzek, a kertben végzett növényi hulladék égetése során a szomszédos területre átterjedő tűz, az eldobott cigaretta vagy az erdőgazdálkodás keretében végzett vágástéri hulladékégetés közben uralhatatlanná váló tűz. ${ }^{14}$

A tudatos gondatlanság (luxuria) kategóriájába sorolta azokat az eseteket, ahol az elkövető elöre látja magatartása következményeinek a lehetőségét, de könnyelmüen bízik azok elmaradásában. Legjellemzőbb formája a luxuriának a gyep, nád, cserje és mezőgazdasági területek évenkénti felgyújtása. A nádastüzek az egész ország területén jellemzők. A gyepes és cserjés területek rendszeres felégetése az észak-magyarországi régióban és a Duna-Tisza közén okoz kezelhetetlen problémát a tavaszi, kiemelten tűzveszélyes időszakban. Nagy szerint

10 44/2011. (XII. 5.) BM rendelet a tűzesetek vizsgálatára vonatkozó szabályokról.

11 Érces Gergő - Bérczi László: A 2017. évi tűzvizsgálati eljárások tapasztalatainak összegzése a mérnöki és kriminalisztikai alapokon nyugvó módszerek értékelésével. Védelem Tudomány, 3.(2018), 1.

12 Bodnár László - Debreceni Péter: Erdő- és vegetációtüzek kialakulásának térbeli és időbeli változásai Magyarországon. In Földi László - Hegedüs Hajnalka (szerk.): Éghajlatváltozás okozta kihívások és lehetséges válaszok. Budapest, Ludovika Egyetemi Kiadó 2020. 301-317.

13 Nagy Dániel: Az erdőtüzek megelőzési és oltástechnológiai lehetőségeinek vizsgálata. Sopron, Nyugat-magyarországi Egyetem, 2008. 35

14 Nagy (2008): i. m. 35. 
„a luxuria ilyenkor már inkább az eshetőleges szándékkal elkövetett cselekménybe hajlik át, hiszen a tủz minden évben átterjed erdőterületre is, így a gyújtogató könnyelmüen nem az ilyen jellegü következmények elmaradásában bízik, hanem beletörődik azok bekövetkezésébe". 15

A vegetációtüzek keletkezési okait a Miskolci Egyetem Szociológiai Intézete is vizsgálta Borsod-Abaúj-Zemplén megyében 2012-ben a NÉBIH Erdészeti Igazgatóságának megbízásából. A kutatásban személyes interjúk és kérdőíves feltárás segítségével mutattak rá a régióban keletkező tüzek okaira. Az egyértelmü jogszabályi tiltás ellenére változatos okai vannak a gondatlan tűzgyújtásnak, kezdve a legelő tavaszi megújításától a gondatlanságon keresztül a figyelemelterelésig. A kutatás szerint több esetben fordult elő, hogy az elkövetők unalomból játszottak a tűzzel vagy „megszokásból” gyújtották azt meg. Gazdálkodók területkezelési vagy vidékfejlesztési támogatás megszerzése céljából gyújtottak meg gyepes, cserjés területet, azonban a tűzgyújtási szabályokat figyelmen kívül hagyva arra előzetesen nem kértek engedélyt a katasztrófavédelemtől, és nem gondoskodtak a tűz őrzéséről. ${ }^{16} \mathrm{~A}$ szándékosan gyújtott tüzek aránya a vizsgált időszakban mindössze 2,2\%. Szándékosnak minősíthetők azok a vegetációtüzek, ahol az elkövető a következményeket kívánja vagy a következményekbe belenyugszik. ${ }^{17}$ Természetes tüzkeletkezési ok a vizsgált adatlapok mindössze 0,9\%-nál lett jelezve. Magyarországi klimatikus viszonyok között természetes oknak elsősorban a nyári zivatarok idején tapasztalható, megnövekvő villámaktivitás tekinthető. ${ }^{18}$ Dinga Szabolcs kérdőíves kutatással és személyes interjúkkal térképezte fel a Heves megyében keletkező vegetációtüzek okait. A válaszok döntő részében a fentieket megerősítő válaszokat kapott, azaz a gondatlanságot, a szándékosságot és a holt biomassza megsemmisítésére irányuló tüzgyújtást jelölték meg a válaszadók. ${ }^{19}$

\section{A Tüzeseti és Müszaki Mentési Jelentésben rögzített tűzkeletkezési okok}

A TMMJ-ben nyolc különböző tűzkeletkezési ok kerül megkülönböztetésre az OKF utasítás szerint. Ezenfelül további három kóddal lehet jelölni, ha nem áll elég információ rendelkezésre a tűzkeletkezési ok meghatározására (ismeretlen, nincs adat, nem sorolható kategóriákba). Az Erdőtűz-adatlapokon rögzített tűzkeletkezési okokat az alábbiakban mutatom be. Ki kell hangsúlyozni, hogy az adatlapon megjelölt tűzok statisztikai célból kerül rögzítésre, ezért a vonatkozó szabályozás szerint nem szükséges annak bizonyítottsága vagy bizonyíthatósága.

5 Nagy (2008): i. m. 35.

16 Szabó-Tóth Kinga: Az erdőtüzek szociológiai vizsgálata Borsod-Abaúj-Zemplén megyében. Empirikus kutatások és elemzések. Miskolc, Miskolci Egyetem Szociológiai Intézet, 2012.

17 Nagy (2008): i. m. 35.

18 Nagy (2008): i. m. 35.

19 Dinga Szabolcs: Vegetációtüzek környezeti hatásai és megelözési lehetöségei Heves megyében. Sopron, Nyugatmagyarországi Egyetem Erdőmérnöki Kar. IV. kari tudományos konferencia tanulmánykötete. 2004. 34-39. 
Az elmúlt évtized tűzesetadatait vizsgálva megállapítható, hogy 2012-ben háromszor annyi vegetációtűz keletkezett, mint az évtized többi évében. A TMMJ-adatlapok „a tűz oka"-rovatában, illetve a szövegesmegjegyzés-mezőben rögzített adatok alapján az alábbi tűzokok mutathatók ki hazánkban. Elektromos energia által okozott tüzek, ezek közé tartoznak az elektromos szikra vagy a kábelek túlterhelése vagy szakadása miatt keletkező tüzek. Ugyanakkor idesorolhatók a villámlás által közvetlen vagy közvetett módon keletkező tűzesetek is, vagyis ez a kategória az emberi tevékenység mellett egy természetes tủzkeletkezési okot is jelenthet a statisztikában. A természetes tűzokok közül a villámlás okoz erdő- és vegetációtüzet aszályos nyarakon, amikor az altalajon található száraz, még nem humifikálódott növényi részek gyulladhatnak meg. Dohányzás nagy számban okoz vegetációtüzeket vonalas létesítmények mellett autóból, vonatból, kerékpárról kidobott, eldobott izzó cigarettacsikkek következtében. A szabadban történő tüzelés során a nyílt láng használata okozza a legtöbb vegetációtüzet. Ezek döntő részben területkezelési célból gyújtott tüzek. A hulladék-, a tarló- vagy a cserjés-, nádas- és gyepégetés a leggyakoribb formája, azonban idesorolhatók a nyílt lángú világítóeszköz vagy mechanikai szikra által okozott tűzesetek is. Ezek a tüzek gyakran átterjednek erdőterületekre is. A tavaszi időszakban gyakori a nyárfa pihéjének meggyulladása véletlen, ritkábban szándékos közremüködéssel. Erdőterületen fakitermelési időszakban a gondatlanul végzett vágástéri hulladékégetésből keletkeznek tüzek. Aratás utáni tarlóégetés során is terjedt át tüz gyepes, cserjés vagy erdős vegetációra. Szintén kimutatható tűzok az elszáradt növényi maradványok megsemmisítésére irányuló égetés, amely szeles időben uralhatatlanná is válhat. Vonalas létesítmények (közút, vasút) mellett kidobott izzó cigaretta miatt keletkezett tűz számos esetben. Vasútvonal mentén tavasszal és nyáron keletkeztek tüzek a vasúti szerelvény fékrendszeréből kicsapó szikrák miatt is. Hőtermelő berendezés által okozott tüzek közé sorolhatjuk azokat, amelyeket tüzelő-, fütő- vagy szárítóberendezés túlhevülése vagy az abból kihulló szikra, parázs okoz. Öngyulladás során a széna vagy a silózott anyagok semmisülnek meg. Robbanás esetén elsősorban a pirotechnikai anyagok okozta tűz terjed át a természetes növénytakaróra. Technológiai hibaként kerül rögzítésre az a tüzeset, ahol egy berendezés szerkezeti vagy technológiai meghibásodása okoz tüzet.

"Ismeretlen” és „nincs adat” tűzkeletkezési ok megjelölése esetén nem állt elegendő adat a tűzoltásvezető rendelkezésére annak meghatározására. A tűzesetek elhanyagolhatóan kis részében a tűzkeletkezés oka semelyik meghatározott kategóriába sem sorolható. Gépjárműtüzeset során az üzemelés közben felforrósodó anyag, szikra kibocsátása okozza a tüzet. Az 1. számú táblázatban vetettem össze a helyszínen rögzített tüzkeletkezési okot az Erdő és Vegetációtűz Felviteli adatlapon megadott négy kategóriával. 
1. táblázat. A tűzkeletkezési okok 2011-2020 közti vegetációtüzeknél a TMMJ- és EVF-adatlapokon

\begin{tabular}{|c|c|c|c|c|c|}
\hline \multirow{2}{*}{ Tüz oka a TMMJ-adatlapon } & \multirow{2}{*}{$\begin{array}{l}\text { Vegetációtüz } \\
\text { esetszám } \\
\text { (db) }\end{array}$} & \multicolumn{4}{|c|}{ Tüz oka az Erdötüz adatlapon } \\
\hline & & Természetes & Hanyagság & Szándékosság & Ismeretlen \\
\hline Dohányzás & 613 & 1 & 514 & 3 & 95 \\
\hline Elektromos energia (villámlás is) & 181 & 48 & 91 & 0 & 42 \\
\hline Hőtermelő berendezés & 8 & 0 & 7 & 0 & 1 \\
\hline Nyílt láng & 10788 & 64 & 3673 & 684 & 6367 \\
\hline Öngyulladás & 126 & 89 & 10 & 0 & 27 \\
\hline Robbanás & 6 & 2 & 2 & 0 & 2 \\
\hline Technológiai hiba & 136 & 4 & 110 & 0 & 22 \\
\hline Ismeretlen & 11116 & 48 & 328 & 29 & 10711 \\
\hline Nincs adat & 40126 & 293 & 4885 & 696 & 34252 \\
\hline $\begin{array}{l}\text { A tüzkeletkezés oka semelyik meghatáro- } \\
\text { zott kategóriába sem sorolható }\end{array}$ & 57 & 1 & 20 & 2 & 34 \\
\hline Gépjármü-tüzeset & 18 & 4 & 11 & 0 & 3 \\
\hline Összesen: & 63175 & 554 & 9651 & 1414 & 51556 \\
\hline
\end{tabular}

Forrás: a szerző szerkesztése a BM OKF KAP Online és a NÉBIH Erdőtűz Információs Rendszer adatai alapján

A statisztikai adatok megerősítik a korábbi, szakemberekkel készített interjúk és a szociológiai felmérés eredményét. A vegetációtüzek döntő mértékben nyílt láng használata miatt következnek be. Emellett a dohányzás és bizonyos időjárási körülmények között az elektromos energia (villámlás formájában) játszik még jelentős szerepet a tủzkeletkezésben. A technikai jellegű tűzokok közül a technológiai hibák fordulnak elő nagyobb számban, amelyek főként az aratáshoz köthető eseményekhez kapcsolódnak.

Az 1. táblázat segítségével megállapítható az is, hogy kis számban ugyan, de előfordulnak téves adatrögzítések. Ezt jelzik azok az ellentmondások, amikor a nyílt láng, dohányzás, technológiai hiba következtében előálló vagy gépjármü-tűzesetnek látszó tűzkeletkezési ok az Erdőtűz-adatlapon „természetes” tűzokként kerül rögzítésre. Hibás rögzítésnek tekinthető az az eset is, amikor a TMMJ-adatlapon megállapításra került egy tűzkeletkezési ok, majd az Erdőtűz-adatlapon ugyanezt „ismeretlenként” sorolták be. Ezek az esetek vélhetően besorolhatók lennének a hanyagság vagy szándékosság kategóriákba. Ellentmondásosak azok az adatrögzítések is, amikor ismeretlen vagy nincs adat kategóriába sorolják a tűz okát a TMMJ-adatlapon, majd az Erdőtűz-adatlapon mégis besorolják egy meghatározott kategóriába. A 3. ábrán az ismeretlen, a nincs adat és a nem sorolható kategóriákba tűzkeletkezési okokat figyelmen kívül hagytam, így szembetűnőbb a nyílt láng használatra vonatkozó kiugró arány a vegetációtüzeknél. 


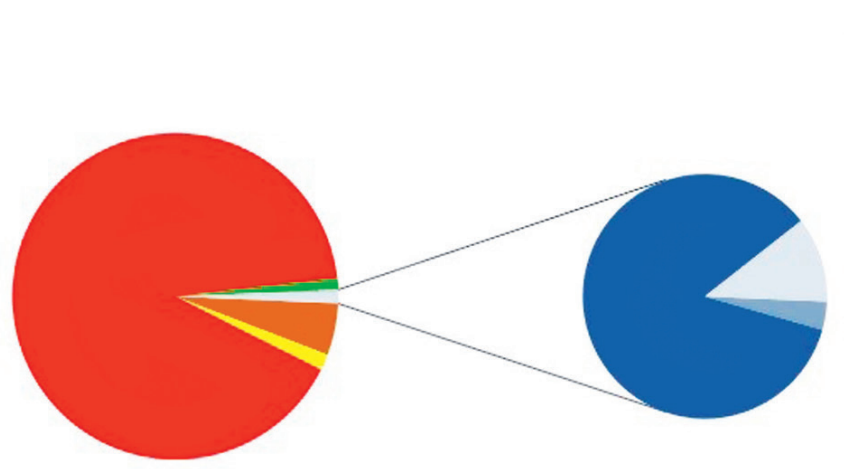

nohányzás

Elektromos energia

- Hőtermelő berendezés

- Nyílt láng

n Öngyulladás

Robbanás

- Technológiai hiba

Gépjármű tűzeset

3. ábra. A 2011-2020 között keletkezett vegetációtüzek tűzkeletkezési okainak megoszlása az ismeretlen vagy nem meghatározható kategóriák nélkül

Forrás: a szerző szerkesztése a BM OKF KAP Online és a NÉBIH Erdőtűz Adattár adatai alapján

A 4. ábrán mutatom be az Erdőtüz-adatlapon rögzített tűzkeletkezési okok arányát. Az ismeretlen tüzkeletkezési ok teszi ki a vizsgált tíz évben az esetek 78,8\%-át.

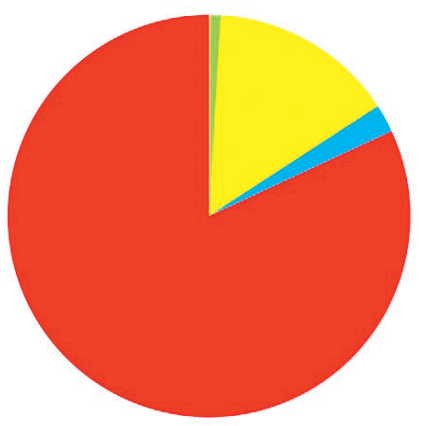

nermészet

- Hanyagság

- Gyújtogatás

- Ismeretlen

4. ábra. Tüzkeletkezési okok megoszlása az Erdőtűz Adatlapon a 2011-2020 között keletkezett vegetációtüzek esetében

Forrás: a szerző szerkesztése a BM OKF KAP Online és a NÉBIH Erdőtűz Adattár adatai alapján

\section{Az ismeretlen tüzkeletkezési ok vizsgálata}

A tủz kiindulási pontjának megtalálása és a tűzkeletkezési ok pontos azonosítása vegetációtüzek esetén sem könnyű feladat. Valamikor nem is lehetséges, és mindig szakképzettséget, magas szintű ismereteket igénylő feladat. Fontosnak tartom itt is kiemelni, hogy a tüzeset helyszínén a tűzoltásvezető által vélelmezett tűzkeletkezési okot kell feltüntetni az adat- 
lapon. A tűzkeletkezési ok statisztikai és kutatási célokból kerül rögzítésre, ezért a vonatkozó szabályozás szerint nem szükséges annak bizonyítottsága vagy bizonyíthatósága. Azokban az esetekben, ahol tűzvizsgálat lefolytatására is szükség van, megállapításra kerülhet a tűzoltásvezető véleményétől eltérő tűzkeletkezési ok is. ${ }^{20} \mathrm{~A}$ tűzvizsgálat tárgyában Érces Gergő és Bérczi László által végzett kutatás egyik eredménye, hogy a keletkezési hely pontos meghatározása, valamint az elsőként gyulladó anyag és a gyújtóforrás azonosítása szükséges a tűzkeletkezési ok pontos meghatározásához. Az utóbbi időben kimutathatóan csökkent az ismeretlen tüzkeletkezési ok megállapítása a tüzvizsgálatok során. Ehhez hozzájárulnak a célirányos gyakorlatok és a szakmai tapasztalatok megosztása. ${ }^{21}$

A 2011-2020 között keletkezett vegetációtüzek tűzkeletkezési okainak vizsgálata is megerősíti a gyakorlatot, azaz az elkövető azonosítása az esetek döntő többségében nem lehetséges. A leégett terület jellegéből és a tűzkeletkezés időpontjában fennálló meteorológiai viszonyok alapján azonban a tűzoltásvezető tehet megállapítást a vélelmezhető tűzkeletkezési okra. A nyílt láng használata az esetek döntő többségében arra utal, hogy növényi hulladék elégetéséről vagy nádas, gyepes terület leégetéséről van szó. A helyszíni adatrögzítés során a TMMJ-adatlapok szöveges mezőjében kerülnek rögzítésre a tűz körülményeire vonatkozó tűzoltásvezetői megállapítások. A vizsgált időszakban rögzített adatlapokon kulcsszavas keresés segítségével gyűjtöttem össze azokat a jellemző kifejezéseket, amelyek azt erősítik meg, hogy a tűzkeletkezési okra vonatkozóan tehetők megállapítások a vegetációtűz jellemzőiről. A leggyakrabban használt kulcsszavak a következők: aljnövényzet, erdő, nádas, gaz, avar, száraz fü, széna, bála, tarló (2. táblázat).

2. táblázat. A TMMJ-adatlapok szöveges mezőjében vegetációtűzre, gondatlan tűzgyújtásra utaló kulcsszavak a tüzesetek arányában (2011-2020)

\begin{tabular}{|c|c|c|}
\hline Évjárat & Vegetációtüz esetszám & Azon tüzesetek aránya (\%), ahol megtalálhatók a keresett kulcsszavak \\
\hline 2011 & 8436 & 84,0 \\
\hline 2012 & 15794 & 87,7 \\
\hline 2013 & 4424 & 88,4 \\
\hline 2014 & 5535 & 84,8 \\
\hline 2015 & 5057 & 84,0 \\
\hline 2016 & 2531 & 84,3 \\
\hline 2017 & 6782 & 82,7 \\
\hline 2018 & 2981 & 81,6 \\
\hline 2019 & 7296 & 81,1 \\
\hline 2020 & 4339 & 83,3 \\
\hline
\end{tabular}

Forrás: a szerző szerkesztése a BM OKF KAP Online és a NÉBIH Erdőtűz Információs Rendszer adatai alapján

20 6/2014. (III. 7.) BM OKF utasítás.

21 Érces-Bérczi (2018): i. m. 
A vizsgált kulcsszavakból kikövetkeztethető tűzhasználat összepárosítható az Európai Erdőtűz Információs Rendszer tűzkeletkezésiok-adatséma elemeivel. A kulcsszavak alapján a hazai vegetációtüzek fő keletkezési okai közé tartoznak: vegetációmenedzsment, mezőgazdasági égetés, hulladékkezelés, üdülési, rekreációs területen végzett tevékenységhez köthető égetés, cigaretta eldobása, elektromos hiba, öngyulladás, villámlás (közvetlen és közvetett ok).

Az EFFIS-be adatot szolgáltató országokban hasonlóan nehézséget okoz a vegetációtűz keletkezési okának meghatározása. Tény, hogy az erdő- és vegetációtüzek a világon mindenütt döntő mértékben antropogén hatások miatt következnek be. Szintén tény, hogy a tüzek kis hányadánál történik tűzvizsgálat, illetve nem fellelhető a tűz kiindulási pontja, ezért a statisztikákban gyakori az ismeretlen tűzok bejegyzése. A sikeres tűzvizsgálat alapja a tűz kiindulási pontjának meghatározása. Az Európai Unió tagországaiban és főként a mediterrán országokban az utóbbi évtizedben számos kutatás indult annak érdekében, hogy a tüzkeletkezési mintákat, tűzkeletkezési okokat jobban megértsük, és ezzel hatékonyabbá váljon az erdőtűzmegelőzési tevékenység. ${ }^{22}$ Egy, az Európai Bizottság Kutatási Központja (Joint Research Center - JRC) által végzett kutatás szerint az utóbbi időben Dél-Európában bekövetkezett társadalmi-gazdasági változások (például a mezőgazdasági területek elhagyása, a vidéki területek elnéptelenedése, a mezőgazdasági és az erdőkezelési módszerek változásai) olyan folyamatokat vezéreltek, amelyek a vegetáció tủzveszélyességét fokozzák a nem kezelt területek növekedése, valamint az éghető holt és élő biomassza felhalmozódása révén. A tűzokséma finomításával és a statisztika pontosításával homogén adatsorok előállítására lesz lehetőség a későbbiekben, ami segíthet a társadalmi és gazdasági változók tüzek bekövetkezésére gyakorolt hatásainak vizsgálatában. ${ }^{23}$

A következő fejezetben röviden áttekintem az EFFIS müködését és a tüzkeletkezési ok meghatározására készített európai javaslatot.

\section{A tüzkeletkezésiok-séma az Európai Erdőtüz Információs Rendszerben}

Az Európai Bizottság kiemelt figyelmet fordít az erdőtüzek megfigyelésére, a tüzek okainak jobb megértésére, és támogatja az erdőtűz-megelőzésben alkalmazható jó gyakorlatok fejlesztését, tagországi alkalmazását. Az EFFIS-t a JRC és az Európai Bizottság Környezetvédelmi Igazgatósága (Directorate General of Environment - DGE) hozta létre annak érdekében, hogy európai szinten is rendelkezésre álljon egy naponta aktualizált, harmonizált adatszerkezettel rendelkező adatbázis. Az adatbázis működtetésén keresztül valósul meg az erdőtüzekre vonatkozó információcsere, a tagállamok és az EU Bizottság által az erdők tűz elleni védelme érdekében tett intézkedések hatásának folyamatos értékelése, a veszélyeztetés időszakának,

22 Luciano Lourenço et al.: Determination of forest fire causes in Portugal (1996-2010). FLAMMA, 4. (2013), 3. 171-175.

23 Lara Vilar et al.: Modelling socio-economic drivers of forest fires in the Mediterranean Europe. Conference: VII. International Conference on Forest Fire Research, 2014. 
mértékének és okának értékelése, valamint az erdők tűz elleni védelmére vonatkozó stratégiák fejlesztése, különös hangsúlyt fektetve a tüzek okainak felszámolására vagy csökkentésére. ${ }^{24}$

A tagországok a nemzeti adatszolgáltatások útján elérhetővé tették az EU Bizottság számára az erdőtüzek alapadatait, így már közösségi szinten is összehasonlítható információk gyűjtése indult meg. ${ }^{25} \mathrm{Az}$ EFFIS-ben alapvetően négy fő tűzok kerül megjelölésre: szándékosság, hanyagság, természetes és ismeretlen. Az EFFIS-be adatot szolgáltató tagországok a négy fö kategórián belül további alkategóriákat alakítottak ki a saját viszonyaik minél részletesebb jellemzésére. Habár az EFFIS az adatok összehasonlítása érdekében tartalmazza az európai adatgyűjtésre meghatározott négy fő kategóriát és a tagországok által kidolgozott alkategóriákat is, harmonizáció hiányában nehézkesen összehasonlíthatók az adatok. Az adatbázist üzemeltető JRC szakértők bevonásával dolgozta ki azt az erdőtüzek okait leíró európai adatsémát, amely magában foglalja a jogszabályokban megadott fő tűzokokat és a tagországok által használt, egységesített, harmonizált tűzkeletkezésiok-kategóriákat. Az új módszer szerint, csak akkor adható meg ismeretlentől eltérő tűz ok, ha meghatározható volt a tűz kiindulási pontja.

Tekintettel arra, hogy a 2011-2020 között keletkezett hazai vegetációtüzek 81,6 \%-ánál a tűzkeletkezés oka ismeretlenként lett meghatározva, javasolt az új adatséma bevezetése és az adatfelvételezés során történő alkalmazása. Így a tagországok adataival összevethetők lesznek a hazai erdőtűzadatok, és egyértelművé válnak mind a statisztikai, mind pedig a tudományos feldolgozás során a tüzok megállapításának körülményei.

Az EFFIS a nemzeti és az európai tűzkeletkezésiok-kategóriákat is tartalmazza. Általános, hogy a tagországok a nemzeti hatáskörben végzett adatgyűjtés során több mint négy kategóriát használnak a tűzkeletkezési ok meghatározására. Amiatt, hogy a tagországok osztályozása különböző szintű, a tűzkeletkezési okok jelentősen eltérhetnek. Az összevethetőséget megcélozva az új tűzkeletkezésiok-adatséma hierarchikusan lett kialakítva, annak érdekében, hogy valóban összehasonlíthatók legyenek az adatszolgáltatások. Az egyes tűzok-kategóriák ezért külön-külön definiálásra kerültek. ${ }^{26}$

Az európai adatséma kulcseleme, hogy a tűz kiindulási pontja meghatározható volt-e vagy sem. A javaslat szerint azokban az esetekben kerüljön csak rögzítésre ismeretlen tűzkeletkezési ok, ha a tűz kiindulási pontját a tűzoltásvezető nem vizsgálta, illetve nem volt lehetséges megtalálni azt, vagy tűzvizsgálat indult, de ez sem hozott eredményt. Ha a tűz kiindulási pontja meghatározható volt és a gyújtóforrás is azonosítható, akkor a tűz keletkezési oka meghatározható és rögzítendő az adatlapon. Abban az esetben, ha a tűz kiindulási pontja nem azonosítható, de a tüz körülményeiből meghatározható a tűzkeletkezési ok, jelölhető az adatbázisban a tüzok meghatározásának részleges bizonytalansága.

24 Az EU Bizottság 804/94/EK rendelete (1994. április 11.) a 2158/92/EGK tanácsi rendeletnek az erdőtüzekre vonatkozó tájékoztatási rendszer tekintetében történő alkalmazására vonatkozó részletes szabályok megállapításáról.

25 Az Európai Parlament és a Tanács 2152/2003/EK rendelete (2003. november 17.) a Közösségen belüli erdők és környezeti kölcsönhatások megfigyeléséről („Forest Focus”).

26 Andrea Camia: Harmonized classification scheme of fire causes in the EU adopted for the European Fire Database of EFFIS. Ispra, Joint Research Center Science and Policy Reports, 2013. 
Az európai tűzkeletkezésiok-osztályozás sémája három hierarchikus szintet tartalmaz annak érdekében, hogy a korábban használt kategorizálás megmaradhasson, illetve az egyes évjáratok adatsorai összehasonlíthatók legyenek. A hierarchikus rendszer lényege, hogy az alapvető tűzkeletkezési kategóriák csoportokra és osztályokra lettek bontva, így a tagországi adatsémákat harmonizálva összesen 29 különböző tűzkeletkezési ok megkülönböztetésére van lehetőség az alapfelosztás (természetes, hanyagság, szándékosság, ismeretlen) meghagyása mellett. Az adatséma teljes leírását az EFFIS weboldalán található technikai leírás tartalmazza. ${ }^{27} \mathrm{Az}$ új osztályozásban a korábbi baleset/hanyagság kódja ketté lesz választva, és egy új kategória, az újragyulladás is bevezetésre került. Minden kategória tartalmaz két alacsonyabb szintet, csoportot és osztályt. A hat fő kategória megnevezése a következő:1. ismeretlen, 2. természetes, 3. baleset, 4. hanyagság, 5. szándékosság, 6 . újragyulladás.

Ismeretlen tűzkeletkezési okot akkor lehet megállapítani, ha a tűz oka nem meghatározható, mert a tűz kiindulási pontja nem felkereshető vagy bizonytalan. Természetes tűzkeletkezési ok rögzítése abban az esetben lehetséges, amikor a tüzet természetes jelenség okozta, emberi beavatkozás nem történt. Baleset akkor következik be vegetációtűz esetén, ha a tüz nem szándékos és közvetetten ember által okozott tűzhasználat nélkül keletkezett, nincs kapcsolatban szándékossággal vagy hanyagsággal és - ritkán - halálos balesethez kötődik. Hanyagság, gondatlanság tűzkeletkezési ok megállapítása esetén a tüzet ember okozta, de nem szándékos tűzhasználattal vagy izzó tárgy használatával, továbbá halálesettel nem hozható összefüggésbe a tüzesemény. Ez a kategória két csoportra osztható. A tủzhasználat csoportjába tartoznak azok a tűzesetek, amikor az ember a tüzet nem szándékosan gyújtotta, például kerti munka során. Azok a tüzek sorolhatók ebbe a csoportba, amelyek kikerülnek az emberi kontroll alól. A hanyagság, gondatlanság kategóriájában a második csoportba az izzó eszköz használata tartozik, amikor a tüzet nem szándékos tűzgyújtás okozta, hanem izzó tárgy használata, például tűzijáték, cigaretta, forró hamu vagy füstölés, fertőtlenítés. Szándékos tűzről beszélünk, amikor a tüzet ember okozta szándékos tűzgyújtással. A szándékos kategória szintén két csoportra osztható. Gyújtogatással állunk szemben, amikor a tüzet nagykorú személy akaratlagosan gyújtotta és a tűz átterjedt a környező növényzetre vagy ingatlanra a tulajdonos engedélye/hozzájárulása nélkül. Beszámíthatatlanságról beszélünk, ha a tüzet olyan ember okozta, aki nem felelős a tetteiért, mert még kiskorú vagy mentális beteg. Visszagyulladás tűzkeletkezési okot kell megjelölni abban az esetben, ha egy korábbi tüz visszagyulladt rejtett hőforrás vagy parázslás miatt.

Az EFFIS-ben a korábbi évek adatszolgáltatásai alapján felülvizsgálták a tagországok által megjelölt tűzokokat, és ahol lehetséges volt, megfeleltették az új adatsémának. A 3. táblázatban javaslatot teszek a hazai rendszerrel elképzelhető megfeleltetésre.

27 Vö. Camia (2013): i. m. 
3. táblázat. A TMMJ-adatlapokon használt tűzkeletkezési okok kategóriáinak lehetséges megfeleltetése az európai adatsémának

\begin{tabular}{|c|c|}
\hline Tüzkeletkezési ok hazai megnevezése & EU-osztályozásnak megfelelö tüzkeletkezési ok \\
\hline Ismeretlen & Ismeretlen \\
\hline Egyéb ok & Ismeretlen \\
\hline Elektromosság vagy villám & Villámlás \\
\hline Technikai hiba & Munkálatok \\
\hline Öngyulladás & Öngyulladás \\
\hline Robbanás & Egyéb baleset \\
\hline Nyilt láng & Egyéb gondatlan tüzhasználat \\
\hline Nyílt láng & Szándékosság \\
\hline Dohányzás & Cigaretta \\
\hline
\end{tabular}

Az európai megfeleltetés azt mutatja, hogy nem lehetséges minden hazai tűzkeletkezési ok egyértelmű megfeleltetése, illetve az európai adatsémában használt tűzkeletkezési okok helyenként más fogalmat használnak, mint ami a hazai adatgyűjtésben eddig előírás volt. A 4. táblázatban tüntetem fel az európai adatsémából azokat a tűzkeletkezésiok-kategóriákat, amelyekkel a hazai vegetációtüzek gondatlanságként besorolt vagy ismeretlen kategóriában értelmezett esetei jellemezhetők. Az európai adatséma pontos fogalommeghatározásokat tartalmaz, így lehetőség van azok egyeztetésére a hazai fogalmakkal.

4. táblázat. Kivonat az európai adatsémából

\begin{tabular}{|c|c|c|}
\hline Kategória & Csoport & Osztály \\
\hline \multirow{7}{*}{300 - Baleset } & \multirow{7}{*}{$300-$ Baleset } & 301 -Elektromosság \\
\hline & & 302 - Közúti, vasúti \\
\hline & & 303 - Jármü \\
\hline & & 304 - Munkálatok \\
\hline & & 305 - Fegyver (löfegyver, robbanóanyag) \\
\hline & & 306 - Öngyulladás \\
\hline & & 307 - Egyéb baleset \\
\hline \multirow{9}{*}{400 - Hanyagság, gondatlanság } & \multirow{5}{*}{410 - Tüzhasználat } & 411 - Vegetáció-menedzsment \\
\hline & & 412 - Mezőgazdasági égetés \\
\hline & & 413 - Hulladékkezelés \\
\hline & & 414 - Üdülés, rekreáció \\
\hline & & 415 - Egyéb gondatlan tűzhasználat \\
\hline & \multirow{4}{*}{420 - Izzó eszköz használata } & 421 - Tüzijáték, petárda, segélyhívó fáklya \\
\hline & & 422 - Cigaretta \\
\hline & & 423 - Forró hamu \\
\hline & & 424 - Egyéb izzó eszköz használata \\
\hline
\end{tabular}

Forrás: a szerző szerkesztése az európai erdőtűzokok sémája alapján 
Az erdő- és vegetációtüzek földrajzi elhelyezkedésének és a tüzek okainak összevetésével definiálhatók az emberi viselkedésből következő kockázatok, és meghatározhatók azok a társadalmi csoportok, amelyek megfelelő informálása által növelhető a tudatosság és a tájékozottság szintje. A lehetséges célcsoportok tűzmegelőzési szempontból: a veszélyeztetett területek lakossága, a gazdálkodók, a hobbikertek tulajdonosai fenyves területek közelében, a dohányzó gépkocsivezetők, az erdészeti és természetvédelmi szakemberek, a katasztrófavédelem hivatásos állománya, a polgári védelmi feladatot ellátó személyek, az oktatási intézmények oktatói és diákjai, a civil szervezetek képviselői. A vidéki lakosság elsősorban a gazdálkodási tevékenység, az urbanizált lakosság pedig a turizmus kapcsán találkozik az erdő- és vegetációtüzekkel. Az egyes célcsoportok nagyok és heterogén összetételűek. A célcsoportokat ezért egyértelműen el kell különíteni, és feléjük célzott üzeneteket kell küldeni, irányukban úgynevezett célcsoportos tájékoztatás ${ }^{28}$ kell végezni. Az egyes célcsoportok részére specifikusan összeállított oktatási anyagok, médiaüzenetek segítségével eljuttathatók azok az ismeretek, amelyek segítik a tudatos tűzhasználatot és a tűzvédelmi szabályok megértését, betartását. A tűzokok ismerete segítséget nyújt továbbá a tűzkockázat csökkentésére irányuló tűzpásztarendszer tervezése során is a pászta típusának és szélességének meghatározásához. ${ }^{29} \mathrm{Az}$ erdő és a lakott területek találkozásánál kialakítandó védőzónák megtervezésekor ugyancsak szükséges ismerni az adott vidéken előforduló tüzokokat. ${ }^{30}$

\section{8. Összegzett következtetések}

A kutatás során megvizsgáltam a 2011-2020 között keletkezett vegetációtüzek keletkezési okait. Áttekintettem azokat a hazai szakirodalmakat, amelyek korábban vizsgálták a kérdést és megállapításokat tettek az adatgyűjtésbe és a tűzvizsgálatba beépíthető szempontokra. Adatbázist állítottam össze a vegetációtüzek keletkezési okairól, és összehasonlítottam a TMMJ- és az Erdőtűz-adatlapon rögzített tűzkeletkezési okokat. Megállapítottam, hogy szükség van egy harmonizált tűzkeletkezésiok-adatséma bevezetésére, amely lehetővé teszi az egyes évjáratokban rögzített adatsorok összehasonlítását, és amely beépítésre kerülhet az Európai Erdőtűz Információs Rendszerbe történő adatszolgáltatásba is. A harmonizált tűzkeletkezésiok-adatséma bevezetése lehetőséget teremt arra is, hogy a tűzvizsgálati tevékenység során a tűzkeletkezési ok könnyebben megállapítható legyen. A tűzkeletkezési ok meghatározásának fontos eleme a tủz kiindulási pontjának megállapíthatósága. A meghatározhatóságra vonatkozó információ (nincs információ, nincs vizsgálva, bizonytalan, meghatározható) feltüntetésével javulhat az adatgyűjtés színvonala, és további tapasztalatokat szerezhetnek a tűzoltásvezetők és tủzvizsgálók a vegetációtüzek vélelmezett keletkezési okainak megha-

28 Az erdőtűz-megelőzés kommunikálásakor alkalmazott technika, amelynek keretében általános figyelemfelkeltő üzenetek és kiválasztott csoportok részére készülő részletes oktatási anyagok alkalmazására kerül sor.

29 Bodnár László: Az erdőtűz kockázatának csökkentési lehetőségei Magyarországon. Védelem Tudomány. Katasztrófavédelmi Online Tudományos Folyóirat, 2. (2017), 2. 1-11.

30 Bodnár László: Lakott területet érintő erdőtüzek vizsgálata, és a védekezés egyes lehetőségei. Hadmérnök, 15. (2020), 1. 45-61. 
tározásáról. Mindez erősítheti azt a szándékot is, hogy a vegetációtüzek keletkezési okaira irányuló adatgyűjtés statisztikai és tudományos célból kerüljön végrehajtásra. A tűzkeletkezési okok statisztikai elemzése segítséget nyújthat az egyes országrészekben keletkező tüzek jobb megértéséhez és a célcsoportos tájékoztatás helyének és idejének megfelelő kiválasztásához.

\section{Felhasznált irodalom}

Bodnár László: Az erdőtűz kockázatának csökkentési lehetőségei Magyarországon. Védelem Tudomány. Katasztrófavédelmi Online Tudományos Folyóirat, 2. (2017), 2. 1-11. Elérhetőség: www.vedelemtudomany.hu/articles/01-debreceni-bodnar-pellerdi.pdf

Bodnár László: Lakott területet érintő erdőtüzek vizsgálata, és a védekezés egyes lehetőségei. Hadmérnök, 15. (2020), 1. 45-61. Online: https://doi.org/10.32567/hm.2020.1.4

Bodnár László - Debreceni Péter: Erdő- és vegetációtüzek kialakulásának térbeli és időbeli változásai Magyarországon. In Földi László - Hegedűs Hajnalka (szerk.): Éghajlatváltozás okozta kihívások és lehetséges válaszok. Budapest, Ludovika Egyetemi Kiadó, 2020. 301-317. Online: https:// nkerepo.uni-nke.hu/xmlui/bitstream/handle/123456789/15313/833_Eghajlatvaltozas.pdf; jsessionid=E0758F6FEEBAAC1A7E736C9A8E086D53? sequence $=1$

Camia, Andrea: Harmonized classification scheme of fire causes in the EU adopted for the European Fire Database of EFFIS. Ispra, Joint Research Center Science and Policy Reports, 2013. Online: http:// effis.jrc.ec.europa.eu/media/cms_page_media/42/LB-NA-25-923-EN-N.pdf

Dinga Szabolcs: Vegetációtüzek környezeti hatásai és megelözési lehetöségei Heves megyében. Sopron, Nyugat-magyarországi Egyetem Erdőmérnöki Kar. IV. kari tudományos konferencia tanulmánykötete. 2014. 34-39.

Érces Gergő - Bérczi László: A 2017. évi tǔzvizsgálati eljárások tapasztalatainak összegzése a mérnöki és kriminalisztikai alapokon nyugvó módszerek értékelésével. Védelem Tudomány. Katasztrófavédelmi Online Tudományos Folyóirat, 3. (2018), 1.

Lourenço, Luciano - Sofia Fernandes - Adélia N. Nunes - Antonio José Bento-Goncalves: Determination of forest fire causes in Portugal (1996-2010). FLAMMA, 4. (2013), 3. 171-175. Online: www. researchgate.net/publication/275581942

Nagy Dániel: Az erdőtüzek megelőzési és oltástechnológiai lehetőségeinek vizsgálata. Sopron, Nyugat-magyarországi Egyetem, 2008.

Szabó-Tóth Kinga: Az erdőtüzek szociológiai vizsgálata Borsod-Abaúj-Zemplén megyében. Empirikus kutatások és elemzések. Miskolc, Miskolci Egyetem Szociológiai Intézet, 2012.

The European Fira Database, Technical specifications and data submission, JRC Science and Policy Reports, Andrea Camia, Tracy Durrant, Jesus San-Miguel-Ayanz, Online: http://effis.jrc.ec.europa. eu/media/cms_page_media/42/EUDB_tech_spec_FINAL_2Register.pdf

Vilar, Lara - Andrea Camia - J. San-Miguel-Ajanz: Modelling socio-economic drivers of forest fires in the Mediterranean Europe. Conference: VII. International Conference on Forest Fire Research, 2014. Online: https://doi.org/10.14195/978-989-26-0884-6_209

\section{Jogi források}

4/2008. (VIII. 1.) ÖM rendelet az erdők tüzvédelméről. Online: https://net.jogtar.hu/jogszabaly?do$\mathrm{cid}=\mathrm{a} 0800004 . \mathrm{onm}$

44/2011. (XII. 5.) BM rendelet a tüzesetek vizsgálatára vonatkozó szabályokról. Online: https://net. jogtar.hu/jogszabaly?docid=A1100044.BM\&celpara=\&dbnum=1 
6/2014. (III. 7.) BM OKF utasítás a katasztrófavédelmi szervek és a tűzoltóságok tűzoltási és műszaki mentési tevékenységének adatszolgáltatási rendjéről. Online: https://net.jogtar.hu/ getpdf? docid=A14U0006.OKF\&targetdate=\&printTitle=6/2014.+\%28III.+7.\%29+BM+OKF+utas\%C3\%ADt\%C3\%A1s\&getdoc=1

A Belügyminisztérium Országos Katasztrófavédelmi Főigazgató 56/2016. számú intézkedése a tűzesetek vizsgálatára vonatkozó egyes eljárási kérdések szabályozásáról.

Az EU Bizottság 804/94/EK rendelete (1994. április 11.) a 2158/92/EGK tanácsi rendeletnek az erdőtüzekre vonatkozó tájékoztatási rendszer tekintetében történő alkalmazására vonatkozó részletes szabályok megállapításáról. Online: https://eur-lex.europa.eu/legal-content/HU/ TXT/?uri=CELEX\%3A31994R0804

Az Európai Parlament és a Tanács 2152/2003/EK rendelete (2003. november 17.) a Közösségen belüli erdök és környezeti kölcsönhatások megfigyeléséröl (Forest Focus). Online: https://eur-lex. europa.eu/legal-content/HU/ALL/?uri=CELEX:32003R2152

Az Európai Erdőtűz Információs Rendszer működtetéséről szóló 1737/2006/EK rendelet.

\section{Adatbázis-segédletek}

Erdőtüz Információs Rendszer. Budapest, Nemzeti Élelmiszerlánc-biztonsági Hivatal, Erdészeti Igazgatóság.

Katasztrófavédelmi Adatszolgáltató Program („KAP Online”). Budapest, Magyarország Belügyminisztériuma, Országos Katasztrófavédelmi Főigazgatóság.

Kitöltési segédlet a Tüzeseti/Müszaki Mentési Adatlaphoz. BM OKF (2019). 